Annals of Plant Sciences

ISSN: 2287-688X

OPEN ACCESS

www.annalsofplantsciences.com

Research Article

\title{
Induced drought and salinity tolerance in the variants of Brassica campestris (L.).
}

Gopal Krishna Shukla

Plant Genetics Laboratory, Department of Botany, Lucknow University, Lucknow 226007, India.

Received: 7/30/2017; Accepted: 8/30/2017

Abstract: The variants obtained from $\mathrm{M}_{2}$ generation of gamma irradiated toria varieties, T-9 and PT303 of Brassica campestris (L.) were evaluated for drought and salt tolerance. Among them, variant TV4 of var. T-9 and the variants PD3 and PD4 of PT303 showed significantly higher antioxidant enzyme activities, proline content, relative water content percentage and yield per plant under these stress conditions. These variants appear more adaptive which may be assigned to their induced favorable genotypic alterations, and could be utilized for developing drought and salinity tolerant Brassicas.

Keywords: Brassica campestris (L.), drought, salinity, stress, tolerance, variants.

\section{Introduction}

Brassica campestris (L.) is an important edible oil yielding crop and occupies second position in the world in oilseed production. In developing countries their production lags behind than its present requirement due to several environmental stresses and non-availability of desirable improved genotypes. Among them drought and salinity are the major abiotic stresses conflicting the crop productivity in arid and semi arid regions. These stresses negatively affect many physiochemical processes of plants leading to accumulation of ROS and reduction in growth and yield. Screening of desirable genetic variability is prerequisite for developing drought and salt resistant genotypes in Brassica. The genetic variability may be induced and exploited through mutagenesis.

Plant adopts to stress by different mechanisms including changes in various morphological and physiological processes (Munns 2000, Zhou 2001). Hence assessment of these processes is an important criterion for the selection of drought and salt tolerant genotypes with better capacity to grow under drought and salt affected soil, and leading to increased net cropped area which may consequently lead to enhanced production.

Thus improvement and evaluation of certain superior Brassica genotypes with enhanced protection from oxidative damage and better yield even in stress condition is extremely important. Hence drought and salt tolerance potential of gamma rays induced eight variants of T-9 and PT303 var. of Brassica campestris (L.) was undertaken by physiological, biochemical and yield studies.

\footnotetext{
${ }^{*}$ Corresponding Author:

Dr. Gopal Krishna Shukla,

Plant Genetic Laboratory,

Dept.of Botany, Lucknow University,

Lucknow, India.

E-mail: gkrishnashukla@rediffmail.com
}

\section{Materials and Methods}

The seeds of eight variants obtained from $\mathrm{M}_{2}$ generation of gamma irradiated toria vars. PT303 and T-9 of Brassica campestris (L.) and their parents (Table-1).

Table1. Traits of variants and parents of two Brassica campestris (L.) varieties.

\begin{tabular}{|c|c|c|c|}
\hline Genotypes & Characters & Genotypes & Characters \\
\hline T9 & Parent & PT303 & Parent \\
\hline TV1 & 4-6 Petals & PD1 & Tall and vigour \\
\hline TV2 & $\begin{array}{l}\text { Tall with short } \\
\text { pod }\end{array}$ & PD2 & $\begin{array}{l}\text { Dwarf, bold and } \\
\text { bright seeded }\end{array}$ \\
\hline TV3 & $\begin{array}{l}\text { Vigorous and } \\
\text { high yielding }\end{array}$ & PD3 & $\begin{array}{l}\text { High yielding } \\
\text { with long pod }\end{array}$ \\
\hline TV4 & $\begin{array}{l}\text { Brown and bold } \\
\text { seeded }\end{array}$ & PD3 & $\begin{array}{l}\text { Bold seeds, semi } \\
\text { dwarf }\end{array}$ \\
\hline
\end{tabular}

These seeds were sown in sterilized sand containing PVC pot in glass house condition. Germinated seedlings were then supplied by half strength Hoagland nutrient solution (Hewitt 1968) until plant developed 4-6 expanded leaves. Thereafter, the pots were divided into three lots, one for control and other two for drought and salt treatment. Drought and salinity were created by half strength Hoagland nutrient supplemented with $1 \%$ ( $\mathrm{w} / \mathrm{v})$ Polyethylene glycol and $1 \%(\mathrm{w} / \mathrm{v})$ common salt $(\mathrm{NaCl})$ respectively. The plants were supplied with nutrient solution in respective concentrations regularly. After 10 days of treatment when stress symptoms were obvious, the samples of fresh leaves were collected for estimating antioxidant enzymes activities, total protein, proline content and RWC percentage. At maturity the crop was harvested for total seed yield. Activities of antioxidant enzymes viz. peroxidase and catalase were estimated in leaf tissues according to the method of Luck (1973) and 
Euller and Josephson (1973) respectively. For expressing specific activity, soluble protein contents in the extract was estimated by methods of Lowry et al., (1983). Proline content was estimated as per Bates et al., (1983) and Relative water content percentage was estimated according to Barr and Weatherly (1962).

\section{Statistical analysis}

Triplicate data were summarized as Mean \pm SE. Groups were compared by two factor (Treatment and Variety) analysis of variance (ANOVA) and the significance of mean difference between groups were done by Newman-Keuls post hoc test. A twotailed $(\alpha=2)$ probability $p<0.05$ was considered to be statistically significant. STATISTICA version 6.0 was used for the analysis.

\section{Results and Discussion}

The activities of peroxidase (EC 1.11.1.7) and catalase (EC.1.11.1.6) were found significantly enhanced in the induced variants and their parents on treatment with 1\% Polyethylene glycol and 1\% $\mathrm{NaCl}$. Similar responses were reported in sunflower (Zhang 1996); rice (Shrivalli et al., 2003) under drought and in wheat under salt stress (Sairam et al., 2002). However, significantly higher activities of these antioxidant enzymes were recorded in variant TV4 under both the stress conditions and also it was true for PD4 in drought and PD3 under salt treatment (Table 2, 3). Our results are in consonance with earlier reports that stimulation in the activities of these enzymes were more pronounced in resistant varieties under stress conditions (Gosset et al., 1994, Kraus et al., 1995, Mittova et al., 2004, Asharaf et al., 1990) and it was suggested that the enhancement of antioxidant system is closely related to drought and salt tolerance of the crops.

The proline accumulation was remarkably increased in all the variants under both the treatments and was higher in salt treatment. The variants, TV4, PD3 and PD4 had significantly higher proline accumulation (Table 2 and 3). Increased proline content has earlier been reported in mustard (Alia et al., 1993), wheat (Singh et al., 1983) and sesame (Koca et al., 2007). The genotypic differences in proline accumulation under stress were used as an index for determination of tolerance among the cultivars (Mishra et al., 2005). High proline content plays an important role in cell osmoregulation and protects plants from dehydration under adverse conditions (Saleik et al., 1993).

Relative water content percentage was considerably decreased in all the variants under drought and salt stress. However, among the variants and parents the least significant decrease was also found in TV4, PD4 and PD3 (Table 2 and 3). Similar findings have also been reported in Brassica (Madan et al., 1994), rice (Sairam et al., 2004) under stress condition. The high $\mathrm{RWC} \%$ is to be associated with the high proline content which helps in osmotic adjustment and balances the leaf water status (Aspinal et al., 1981). The greater retention of RWC $\%$ in these variants indicated greater tolerance capacity to withstand drought and salt stress (water deficit conditions).

The yield performance of the variants varied under both the stress conditions. Our results show that the variants TV4, PD4 and PD3 are superior in respect of yield, antioxidant defense system as well as proline content and $\mathrm{RWC} \%$, and could be relatively more adaptive under stress conditions.

\section{Conclusion}

The higher yield and enhancement in antioxidant enzyme activity of variants under both the stresses may be due to induced favorable genotypic alterations by gamma irradiation. These variants can be exploited for developing drought and salinity tolerant Brassicas.

Table 2: Stress parameters (Mean \pm SE, $n=3$ ) of different variants of T-9 at three different treatments;

\begin{tabular}{|c|c|c|c|c|}
\hline \multirow{2}{*}{ Parameters } & \multirow{2}{*}{ Variety } & \multicolumn{3}{|c|}{ Treatments } \\
\hline & & Control & Drought & Salinity \\
\hline \multirow{5}{*}{$\begin{array}{l}\text { Catalase }\left(\mathrm{H}_{2} \mathrm{O}_{2}\right. \\
\text { split/mg protein })\end{array}$} & T-9 & $317.00 \pm 6.08$ & $472.67 \pm 6.39^{c}$ & $392.00 \pm 6.43^{\mathrm{cd}}$ \\
\hline & TV1 & $520.33 \pm 6.06^{\mathrm{a}}$ & $406.00 \pm 5.51^{\mathrm{ac}}$ & $374.67 \pm 5.55^{\mathrm{cd}}$ \\
\hline & TV2 & $452.67 \pm 5.46^{\mathrm{a}}$ & $395.00 \pm 6.43^{\mathrm{ac}}$ & $390.00 \pm 6.08^{c}$ \\
\hline & TV3 & $394.00 \pm 6.03^{a}$ & $416.67 \pm 5.61^{\mathrm{a}}$ & $413.67 \pm 5.78$ \\
\hline & TV4 & $432.33 \pm 5.78^{a}$ & $620.00 \pm 5.86^{a c}$ & $562.00 \pm 6.43^{\mathrm{acd}}$ \\
\hline \multirow{5}{*}{$\begin{array}{l}\text { Peroxidase } \\
\text { (act./mg protein) }\end{array}$} & T-9 & $2.51 \pm 0.10$ & $2.58 \pm 0.07$ & $2.63 \pm 0.09$ \\
\hline & TV1 & $2.27 \pm 0.09$ & $2.53 \pm 0.09$ & $2.27 \pm 0.09$ \\
\hline & TV2 & $1.79 \pm 0.07 \mathrm{a}$ & $1.66 \pm 0.08^{a}$ & $2.02 \pm 0.10^{\mathrm{ad}}$ \\
\hline & TV3 & $1.74 \pm 0.06^{\mathrm{a}}$ & $1.82 \pm 0.10^{\mathrm{a}}$ & $2.31 \pm 0.07 \mathrm{~cd}$ \\
\hline & TV4 & $2.47 \pm 0.08$ & $3.08 \pm 0.07 \mathrm{ac}$ & $3.25 \pm 0.10^{\mathrm{ac}}$ \\
\hline \multirow{5}{*}{$\begin{array}{l}\text { Proline } \\
\text { ( } \mu \mathrm{mol} / \mathrm{mg} \text { f.wt.) }\end{array}$} & T-9 & $42.27 \pm 0.61$ & $52.67 \pm 0.88^{c}$ & $85.30 \pm 0.85^{\mathrm{cd}}$ \\
\hline & TV1 & $37.25 \pm 0.72^{\mathrm{a}}$ & $40.20 \pm 0.76^{\mathrm{ac}}$ & $82.17 \pm 0.73^{\mathrm{acd}}$ \\
\hline & TV2 & $33.23 \pm 0.96^{\mathrm{a}}$ & $40.37 \pm 0.73^{\mathrm{ac}}$ & $76.13 \pm 0.70^{\mathrm{acd}}$ \\
\hline & TV3 & $30.17 \pm 0.73^{a}$ & $31.40 \pm 0.70^{\mathrm{a}}$ & $77.00 \pm 0.75^{\mathrm{acd}}$ \\
\hline & TV4 & $23.33 \pm 0.71^{\mathrm{a}}$ & $44.23 \pm 0.96^{\mathrm{ac}}$ & $95.27 \pm 0.93^{\mathrm{acd}}$ \\
\hline \multirow{4}{*}{ RWC (\%) } & T-9 & $84.87 \pm 0.81$ & $84.33 \pm 0.88$ & $81.00 \pm 0.58^{c}$ \\
\hline & TV1 & $86.00 \pm 1.00$ & $83.20 \pm 0.76$ & $71.40 \pm 0.70^{\text {acd }}$ \\
\hline & TV2 & $85.33 \pm 0.88$ & $83.00 \pm 1.00$ & $72.20 \pm 0.64^{\mathrm{acd}}$ \\
\hline & TV3 & $89.00 \pm 0.58^{\mathrm{a}}$ & $85.17 \pm 0.73^{c}$ & $76.17 \pm 0.66^{\mathrm{acd}}$ \\
\hline
\end{tabular}




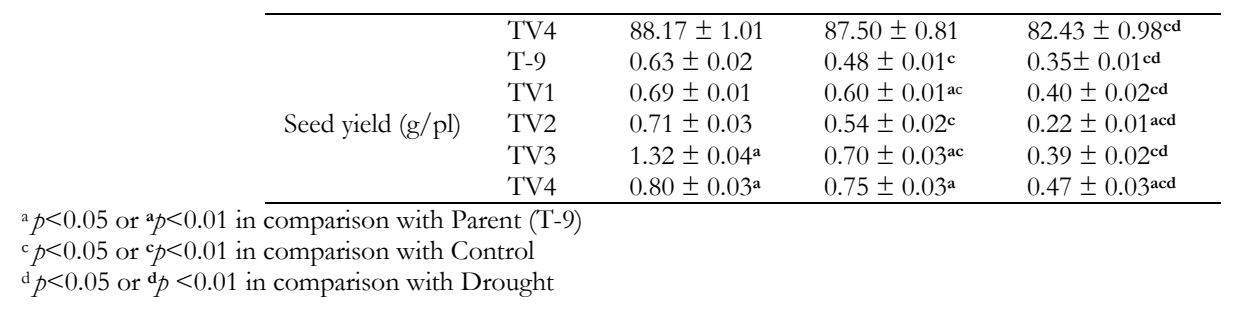

Table3. Stress parameters (Mean \pm SE, $n=3$ ) of different variants of PT303 at three different treatments;

\begin{tabular}{|c|c|c|c|c|}
\hline \multirow{2}{*}{ Parameters } & \multirow{2}{*}{ Variety } & \multicolumn{3}{|l|}{ Treatments } \\
\hline & & Control & Drought & Salinity \\
\hline \multirow{5}{*}{$\begin{array}{l}\text { Catalase }\left(\mathrm{H}_{2} \mathrm{O}_{2}\right. \\
\text { split/mg protein) }\end{array}$} & PT303 & $506.00 \pm 6.08$ & $493.00 \pm 5.69$ & $534.00 \pm 5.86^{\mathrm{cd}}$ \\
\hline & PD1 & $409.67 \pm 6.49^{\mathrm{a}}$ & $527.67 \pm 5.46^{\mathrm{ac}}$ & $477.00 \pm 5.69^{\mathrm{acd}}$ \\
\hline & PD2 & $600.33 \pm 6.57^{a}$ & $532.00 \pm 6.35 \mathrm{ac}$ & $428.33 \pm 5.84^{a c d}$ \\
\hline & PD3 & $520.00 \pm 6.24$ & $492.00 \pm 6.43^{c}$ & $681.67 \pm 6.01^{\mathrm{acd}}$ \\
\hline & PD4 & $611.00 \pm 6.51^{\mathrm{a}}$ & $668.33 \pm 6.57^{\mathrm{ac}}$ & $462.00 \pm 6.11^{\mathrm{acd}}$ \\
\hline \multirow{5}{*}{$\begin{array}{l}\text { Peroxidase } \\
\text { (act./mg protein) }\end{array}$} & PT303 & $1.77 \pm 0.02$ & $1.53 \pm 0.04^{c}$ & $1.90 \pm 0.02^{\mathrm{d}}$ \\
\hline & PD1 & $1.67 \pm 0.03$ & $1.34 \pm 0.03^{a c}$ & $1.87 \pm 0.03^{\mathrm{cd}}$ \\
\hline & PD2 & $1.62 \pm 0.05^{\mathrm{a}}$ & $1.51 \pm 0.05$ & $1.76 \pm 0.04^{\mathrm{cd}}$ \\
\hline & PD3 & $1.47 \pm 0.03^{\mathrm{a}}$ & $1.37 \pm 0.03^{\mathrm{a}}$ & $2.03 \pm 0.05^{\mathrm{acd}}$ \\
\hline & PD4 & $1.11 \pm 0.02^{\mathrm{a}}$ & $1.83 \pm 0.04 a c$ & $1.77 \pm 0.04^{c}$ \\
\hline \multirow{5}{*}{$\begin{array}{l}\text { Proline } \\
(\mu \mathrm{mol} / \mathrm{mg} \text { f.wt.) }\end{array}$} & РT303 & $14.80 \pm 0.40$ & $32.53 \pm 0.26^{\mathrm{c}}$ & $81.53 \pm 0.38^{\mathrm{cd}}$ \\
\hline & PD1 & $15.48 \pm 0.31$ & $20.23 \pm 0.50^{\mathrm{ac}}$ & $78.80 \pm 0.42^{\mathrm{acd}}$ \\
\hline & PD2 & $14.90 \pm 0.21$ & $20.87 \pm 0.47 \mathrm{ac}$ & $62.13 \pm 0.47 \mathrm{acd}$ \\
\hline & PD3 & $14.48 \pm 0.37$ & $19.83 \pm 0.44^{\text {ac }}$ & $83.40 \pm 0.31 \mathrm{acd}$ \\
\hline & PD4 & $19.53 \pm 0.59^{a}$ & $70.65 \pm 0.46^{\mathrm{ac}}$ & $70.50 \pm 0.29 \mathrm{ac}$ \\
\hline \multirow{5}{*}{ RWC (\%) } & PT303 & $89.13 \pm 0.70$ & $85.07 \pm 0.64^{\mathrm{c}}$ & $69.80 \pm 0.74^{\mathrm{cd}}$ \\
\hline & PD1 & $89.53 \pm 0.74$ & $87.40 \pm 0.83$ & $74.77 \pm 0.79 \mathrm{acd}$ \\
\hline & PD2 & $85.07 \pm 0.64^{a}$ & $87.90 \pm 0.86$ & $78.00 \pm 0.81^{\mathrm{acd}}$ \\
\hline & PD3 & $85.90 \pm 0.67^{a}$ & $82.93 \pm 0.69$ & $79.67 \pm 0.88^{\mathrm{acd}}$ \\
\hline & PD4 & $83.82 \pm 0.66^{\mathrm{a}}$ & $83.13 \pm 0.70$ & $78.53 \pm 0.74 \mathrm{acd}$ \\
\hline \multirow{5}{*}{ Yield $(\mathrm{g} / \mathrm{pl})$} & РT303 & $0.72 \pm 0.02$ & $0.58 \pm 0.04^{c}$ & $0.23 \pm 0.03^{\mathrm{cd}}$ \\
\hline & PD1 & $0.92 \pm 0.04^{a}$ & $0.56 \pm 0.03^{c}$ & $0.38 \pm 0.02^{\mathrm{acd}}$ \\
\hline & PD2 & $0.85 \pm 0.05^{\mathrm{a}}$ & $0.52 \pm 0.04^{\mathrm{c}}$ & $0.14 \pm 0.03^{\mathrm{cd}}$ \\
\hline & PD3 & $1.03 \pm 0.05^{\mathrm{a}}$ & $0.84 \pm 0.03 \mathrm{ac}$ & $0.56 \pm 0.02^{\mathrm{acd}}$ \\
\hline & PD4 & $1.26 \pm 0.04^{\mathrm{a}}$ & $1.10 \pm 0.05^{\mathrm{ac}}$ & $0.20 \pm 0.03^{\mathrm{cd}}$ \\
\hline
\end{tabular}

${ }^{a} p<0.05$ or a $p<0.01$ in comparison with Parent(PT303)

$\mathrm{c} p<0.05$ or $\mathrm{c} p<0.01$ in comparison with Control

$\mathrm{d} p<0.05$ or $\mathrm{d} p<0.01$ in comparison with Drought

\section{References}

1. Asharaf, M., and T. McNeilly. "Responses of four Brassica spp. to sodium chloride." Environmental and Experimental Botany 30. (1990): 475-487.Print.

2. Aspinal, D., and L.D. Pelag. "In the physiology and biochemistry of drought resistance in plants" Eds. Pelag, L.G., and D. Aspinal. Academic press. Sydeny (1981): 215-228.Print.

3. Alia, P., Pardhasaradhi and P. Mohonty. "Proline in relation to free redicals production in seedlings of $B$. juncea raised under sodium chloride stress." Plant and soil 155 (1993): 497-500.Print.

4. Barr, L.S., and P. Weatherly. "A reexamination of the relative turgidity techniques for estimating water deficit in leaves". Australian J. of BioSciences 15(1962): 413-428.Print.

5. Bates, L.S., R.P. Waldern and I.D. Teere. "Rapid determination of free proline for water stress studies." Plant and soil 39(1973): 205-207.Print.

6. Euller, H. Von, Josephson et al. "Uberkatalase I leibeg." Annals of chemistry 452 (1927): 158187.Print.
7. Gosset, D.R., E.P. Millholon and M.C. Lucas. "Antioxidant response to $\mathrm{NaCl}$ stress in salt tolerant and salt sensitive cultivars of cotton." Crop Science 34 (1994):706-714.Print.

8. Hewitt, E.J. "Sand and water culture method used in study of plant nutrition." Commonwealth Agricultural Bureaux. Farnham Royal Bank. U.K. (1968): 105-110.Print.

9. Koca, H. et al., "The effect of salt stress on lipid peroxidation, antioxidative enzymes and proline content in Seasame indicum." Environment and Experimental Botany 60 (2007): 344-351.Print.

10. Kraus, E., B. D. McKersie and R.A. Fletcher. "Achobutrazol induced tolerance of wheat leaves to paraquot may involve increased antioxidant enzyme activity." Journal of plant physiology 145 (1995): 570-576.Print.

11. Lowry, O.H., N.J. Rosenberough, A.L. Farr and Randall. "Protein measurement with the folinphenol reagent." Journal of Biological chemistry 193 (1951): 265-275.Print.

12. Luck, H., H.U. Bergmeyer. "Peroxidase In methods in enzymetic analysis." Acadmic press Inc, Newyork. (1974): 895-897.Print. 
13. Madan, S., H.S. Nainawatiee et al., "Leaf position dependent changes in proline-5 carboxylase reductase activity and water relation under salt stressing genetically stable salt tolerant somaclones of Brassica juncea L." Plant Soil 163 (1994): 151156.Print.

14. Mishra, N., A. Gupta. "Effect of salt stress on proline metabolism in two high yielding genotypes of green gram.” Plant Science 169 (2005): 331339.Print.

15. Mittova, V., M. Guy et al., "Salinity upregulates the antioxidant system in root mitochondria and peroxisome in the wild salt tolerant tomato species Lycopersion pennilli." Journal of Experimental Botany 55 (2004): 1105-1113.Print.

16. Munns, R. "Comparative physiology of salt and water stress." Plant cell and Environment. 25 (2002): 239-250.Print.

17. Sairam, R.K., and G. Srivastva. "Changes in antioxidant activity in sub cellular fraction of tolerant and susceptible wheat genotypes in response to long term water stress." Plant Science 162 (2002): 897-904.Print.

18. Sairam, A.K., and A. Tyagi. "Physiology and molecular biology of salinity tolerance in plants." Current science 86 (2004): 407-421.Print.
19. Shrivalli, B., G. Sharma and R. Khanna Chopra. "Antioxidant defense system in upland rice culture subjected to water stress followed by recovery." Physiologia Plantarum 199 (2003): 503-510.Print.

20. Singh, K.P., and K. Singh. "Influence of stimulated water stress in proline accumulation in Triticum aestivum L." Indian journal of Plant Physiology 26.3 (1983): 319-321.Print.

21. Saleik, R., P.G. Yoeng and D.D. Lefobvre. "Mutants of Arabidopsis thaliana capable of germination under saline conditions." Plant Physiology 101 (1993): 839-845.Print.

22. Zhang, J. and M.N.B. Kirkham. "Antioxidant response to drought in sunflower and sorghum seedling." Phytologia 132 (1964): 361-362.Print.

23. Zhou, J.K. "Plant salt tolerance." Trends plant science 6 (2001): 66-71. Print.

\section{Cite this article as:}

Gopal Krishna Shukla. Induced drought and salinity tolerance in the variants of Brassica campestris (L.). Annals of Plant Sciences 6.9 (2017) pp. 1686-1689.

doi: http://dx.doi.org/10.21746/aps.2017.9.4 